\title{
Influence of Exogenous Auxins on Phenolic Compounds Contents and Polyphenol oxidasic and Peroxidasic Activities in Root Differentiation in Gnetum spp.
}

\author{
Minyaka Emile1,2, Simo Claude ${ }^{2,3}$, Medueghue Fofou Apollin'1, Oumar Doungous ${ }^{4}$, \\ Jetro Nkengafac Njukeng ${ }^{4}$, Niemenak Nicolas ${ }^{2}$, Omokolo Ndoumou Denis ${ }^{2}$ \\ ${ }^{1}$ Department of Biochemistry, Faculty of Sciences, University of Douala, Douala, Cameroon \\ ${ }^{2}$ Laboratory of Plant Physiology, Department of Biological Sciences, Higher Teacher's Training College, Yaoundé, Cameroon \\ ${ }^{3}$ Department of Plant Biology, Faculty of Science, Douala, Cameroon \\ ${ }^{4}$ Institute of Agricultural Research for Development (IRAD), Buea, Cameroon \\ Email: *simoclaude@yahoo.fr
}

How to cite this paper: Emile, M., Claude, S., Apollin, M.F., Doungous, O., Njukeng, J.N., Nicolas, N. and Denis, O.N. (2019) Influence of Exogenous Auxins on Phenolic Compounds Contents and Polyphenol oxidasic and Peroxidasic Activities in Root Differentiation in Gnetum spp. Agricultural Sciences, 10, 1073-1089.

https://doi.org/10.4236/as.2019.108081

Received: July 3, 2019

Accepted: August 25, 2019

Published: August 28, 2019

Copyright $\odot 2019$ by author(s) and Scientific Research Publishing Inc. This work is licensed under the Creative Commons Attribution International License (CC BY 4.0).

http://creativecommons.org/licenses/by/4.0/

\section{(c) (i) Open Access}

\begin{abstract}
Root failure is a key limiting factor in Gnetum spp. domestication and production of plants materials for farming. To overcome, root failure in Gnetum spp. may depend on adequate strategies set up and understanding of biochemical markers controlling the rooting process. The present work is principally based on phenolic compounds contents, peroxidasic and polyphenol oxidasic activities during rooting of cuttings (pretreated with IBA, ANA and IAA) at induction, initiation and expression phases of roots formation in Gnetum africanum Welw. and G. buchholzianum Engl. The study revealed that cuttings pretreated with IBA $(150 \mathrm{mg} / \mathrm{l})$ were more effective than IAA and NAA. Phenolic compounds analysis revealed that cuttings pretreated with IBA exhibited high phenolic compound contents at initiation and expression phases for both Gnetum species. Indicating that IBA pretreatment promotes phenolic compounds synthesis and accumulation necessary for roots differentiation. Enzyme contents appear to be high during the initiation stage for both species when they are pretreated with IBA $(150 \mathrm{mg} / \mathrm{l})$. Peroxidasic and Polyphenol oxidasic activities evolved on the synchroneous maner. This allows us to know that the implication of these enzymes in the rooting process is fundamental makers.
\end{abstract}

\section{Keywords}

Gnetum (spp.), Biodiversity, Rhizogenesis, Biochemical Markers, Hormones 


\section{Introduction}

Gnetum spp. is a gymnosperm creeping plant found natively throughout the humid tropical forests areas of Africa countries: Angola (12 $\left.30^{\prime \prime} \mathrm{S} 18^{\circ} 30^{\prime \prime} \mathrm{E}\right)$, Cameroon ( $\left.3^{\circ} 52^{\prime \prime} \mathrm{N} 11^{\circ} 31^{\prime \prime} \mathrm{E}\right)$, Central African Republic ( $\left.7^{\circ} \mathrm{N} 21^{\circ} \mathrm{E}\right)$, Democratic Republic of Congo ( $\left.4^{\circ} 31^{\prime \prime} \mathrm{N} 15^{\circ} 32^{\prime \prime} \mathrm{S}\right)$, Gabon $\left(1^{\circ} \mathrm{N} 11^{\circ} 45^{\prime \prime} \mathrm{E}\right)$ and Nigeria $\left(10^{\circ} \mathrm{N} 8^{\circ}\right.$ E) [1] [2]. In these African countries, Gnetum spp. bears various common names: Angola (KoKo), Cameroon (okok, Eru, m’fumbua, or fumbua), Central African Republic (KoKo), Congo (KoKo), Democratic Republic of Congo (m'fumbua or fumbua), Gabon (KoKo) and Nigeria (ukase or afang) [3].

Nutritionally, Gnetum spp. increases overall food security of rural households. Content of amino acids found in Gnetum spp. is similar to the recommended levels by the FAO. It has also been found that the levels of iodine are also high in the Gnetum spp. Fibers average level is approximately $33.4 \mathrm{~g} / 100 \mathrm{~g}$ of dried Gnetum spp. leaves, while recommended daily intake of fibers is $30 \mathrm{~g}$.

Medicinally, Gnetum spp. has been noted as an anti-inflammatory, anticarcinogenic and antioxidant and good source of protein and has a high content of essential and non-essential amino acids.

Economically, Gnetum spp. can be used as a means to maintain a supplemental income for rural farmers.

Due to its nutritional, medicinal and economical importance, Gnetum spp. is over-harvested. To insure the conservation of this crop and to manage the growing demand, it was planned to domesticate it using root cuttings to produce planting material intended for agricultural holdings. Root cutting is a vegetative and clonal propagation method with advantage of capturing all the genetic superiority without involving any gene segregation [4]. Vegetative propagation is widely used in agriculture, horticulture and forestry for domestication, production of planting materials and multiplying interesting plants [5]. However, adventitious root formation is a key step in root cuttings process in horticulture, agriculture and forestry [6].

Unfortunately, root failure of cuttings limits the domestication and production of Gnetum spp. planting material. Roots formation is one of the three main routes of organogenesis (along with shoot formation and somatic embryogenesis) where cells undergo an apparent reversal of differentiation and again become meristematic prior to differentiation. The rooting capacity of cuttings highly depends on keys factors which include genetic profile (species, genotype), hormonal pool and enzymatic status. Hence, tackle cuttings roots failure in Gnetum spp. is express through exogenous plant hormones, pretreatment and morphogenesis related-enzymes (such as peroxidase and polyphenol oxidase) status will bring new in the improvement of Gnetum spp. domestication and production of useful planting materials through roots cuttings.

Adventitious roots differentiation occurs in three recognized successive phases named induction, initiation and expression [7]. Auxins have been reported to be involved in adventitious roots formation as they are implicated in the inter- 
dependent physiological phases of rooting process [8] [9]. Some authors [10] reported that the effectiveness of auxin application on rooting potential of cuttings is optimal dependently of the adventitious root formation phases. These data may insinuate that auxin profile and pool are a key factor in rooting cutting induction, initiation and expression. It has been reported that adequate auxin synthesis (availability) enhances root formation [11]. Reversely, auxin catabolism (degradation) did not promote rooting. Auxin oxidation is a useful process affecting auxin profile and pool in plant.

Hence, it can be hypothesized that, rooting failure in plant (including Gnetum spp.) could be correlated with physiological or biochemical causes linked to auxin profile, pool and status in plant. Auxin oxidation may stand as controlling factor of auxin profile, pool and status in plant; thus, affecting adventives roots of cuttings.

Investigations on adventitious root formation reported the influence of oxidative enzymes peroxidases and polyphenol oxidases [12] [13]. However, in this field, little or nothing is known about the biochemical events underlying rooting cutting in Gnetum spp. Therefore, the present work studies the influence of exogenous auxin pretreatment on phenolic compounds contents, peroxidase and polyphenol oxidase activities associated with roots differentiation in Gnetum spp.

\section{Materials and Methods}

\subsection{Plant Material}

Plant material made of creepers from Gnetum africanum and Gnetum buchholzianum were harvested early in the morning (6 am) at Ekona (South-West Region, Cameroon) bush "Black bush", saved in room temperature in water and transferred in the laboratory. After morphological identification of each species, cuttings of $7 \mathrm{~cm}$ length were collected from creepers. The surface of cuttings leaves was reduced in order to minimize cutting leaf transpiration.

\subsection{Experiment Design: Soaking Media and Time}

Pretreatment or soaking media were defined using medium of [14], mineral salts complex supplemented (or not) with variable concentrations of auxins (IAA, IBA and NAA) used as regulatory factors. The $\mathrm{pH}$ of all pretreatment media was adjusted (with $\mathrm{KOH}$ or $\mathrm{HCl} 0.1 \mathrm{M}$ solution) to 5.8 prior to cuttings treatment

For each independent experiment, cuttings were soaked for variable periods $(1,6,12$ and 15 hours) prior to culture. Additionally, variable concentrations of IAA, IBA and NAA were screened. The most effective soaking time (12 hours) was combined to the most effective IAA, IBA and NAA concentrations to study the influence of exogenous auxin pretreatment on phenolic compounds contents, peroxidase and polyphenol oxidase activities during roots differentiation in Gnetum spp. Therefore, culture media for the present investigation were defined with MS mineral salts complex combined (or not) to IAA (150 mg/l), IBA (150 mg/l) and NAA (100 mg/l) (Table 1). 
Table 1. Cutting soaking media.

\begin{tabular}{ccccc}
\hline Gnetum spp. & MS (g/l) & IAA (mg/l) & IBA (mg/l) & NAA (mg/l) \\
\hline & 0 & 0 & 0 & 0 \\
G. africanum & 2.185 & 0 & 0 & 0 \\
& 2.185 & 150 & 0 & 0 \\
& 2.185 & 0 & 150 & 0 \\
& 2.185 & 0 & 0 & 100 \\
& 0 & 0 & 0 & 0 \\
G. buchholzianum & 2.185 & 0 & 0 & 0 \\
& 2.185 & 150 & 0 & 0 \\
& 2.185 & 0 & 150 & 0 \\
\hline
\end{tabular}

Cuttings from creepers of each Gnetum spp. species were subdivided into five sets of 20 cuttings. One set (not soaked) was used as negative control; another set (soaked in MS solution) was used as positive control. The three others sets (soaked in MS solution supplemented with $150 \mathrm{mg} / \mathrm{l} \mathrm{IAA}, 150 \mathrm{mg} / \mathrm{l} \mathrm{IBA}$ or 100 mg/l NAA) were used as test (Table 1).

\subsection{Culture Monitoring}

Soaked and not soaked cuttings were randomly cultured into a propagator. After culture, cuttings were watered daily at 6 am with the same quantity (12 liters) of tape water for eight weeks. Five independent experiments were conducted for all soaking media and for both Gnetum spp. species ( $G$. africanum and $G$. buchholzianum).

Besides, watering cultures cuttings were collected, 5 (induction phase), 12 (initiation phase) and 20 (expression phase) days after culture in the propagator. The basal part of the collected cuttings was used for biochemical investigations.

\subsection{Biochemical Analysis}

\subsubsection{Phenolic Compounds Extraction and Quantification}

Phenolic compounds were extracted from fresh basal parts (with or without roots) of Gnetum spp. cuttings following the adapted method of [15]. In brief, $0.2 \mathrm{~g}$ of biological material was ground and homogenized in $1.4 \mathrm{ml}$ acetone $\left(80 \%\right.$ at $25^{\circ} \mathrm{C}$ ) and centrifuge (6000 g, $20 \mathrm{~min}$, room temperature). Super reagents (phenolic compounds crude extracts) were collected in $1.5 \mathrm{ml}$ microtubes and stored at $-20^{\circ} \mathrm{C}$.

Phenolic compounds contents were estimated with the Folin Ciocalteu reagent at $750 \mathrm{~nm}$ according to the procedure of [16]. In summary, successively, 2 $\mathrm{ml}$ of distilled water, $100 \mu \mathrm{l}$ of phenolic compounds crude extract, $200 \mu \mathrm{l}$ Folin Ciocalteu reagent and $0.5 \mathrm{ml}$ of $\mathrm{Na}_{2} \mathrm{CO}_{3}(20 \%)$ were mixed, homogenized and 
incubated for $20 \min \left(40^{\circ} \mathrm{C}\right)$. After incubation, the optical density was read at $725 \mathrm{~nm}$ against a blank where phenolic compounds crude extract was replaced with equal volume of acetone $80 \%$.

Phenolic compounds contents were determined by reference to standards established with pure analytical grade chlorogenic acid and expressed on a fresh weight basis ( $\mu \mathrm{g} / \mathrm{g}$ of FW).

\subsubsection{Polyphenol oxidase and Peroxidase Extraction}

The protein content was determined by the method of Bradford using bovine serum albumin (BSA) as a blank [17]. Polyphenol oxidase and peroxidase were extracted using the adapted method of [18]. Briefly, approximately $1 \mathrm{~g}$ of fresh basal parts (with or without roots) of Gnetum spp. cuttings were ground and homogenized in mortar containing $10 \mathrm{ml}$ potassium phosphate buffer $(50 \mathrm{mM}$, $\mathrm{pH}$ 6.0). The homogenate was subsequently centrifuged $\left(6000 \mathrm{~g}, 30 \mathrm{~min}\right.$ at $\left.4^{\circ} \mathrm{C}\right)$ and the supernatant was collected. The pellet was re-suspended in the same buffer centrifuged under the same conditions as previously. The second supernatant was added to the first to obtain peroxidase and polyphenol oxidase fresh preparation extract (in $1.5 \mathrm{ml}$ microtubes and stored at $-20^{\circ} \mathrm{C}$ ) which were used for polyphenol oxidasic and peroxidasic activity assays.

\subsubsection{Polyphenol oxidase and Peroxidase Activities}

1) Polyphenol oxidase activity

Polyphenol oxidase (PPO) activity was determined by measuring the increase in absorbance at $330 \mathrm{~nm}$ using method of [19]. The reaction mixture incubated at $25^{\circ} \mathrm{C}$ was made of $2.7 \mathrm{ml}$ of phosphate buffer $(1 / 15 \mathrm{M}, \mathrm{pH} 6.1)$ and $0.3 \mathrm{ml}$ cathecol $(10 \mathrm{mM})$. The reaction was initiated by adding $40 \mu \mathrm{l}$ of enzymatic extract. The enzyme activity was monitored through change of optical density at $330 \mathrm{~nm}$ after $30 \mathrm{~s}$. PPO activity was expressed in UE per $\mu \mathrm{g}$ of proteins content.

\section{2) Peroxidase activity}

Peroxidase (POD) activity was determined using method of [20]. Guaïacol transformation was followed at $420 \mathrm{~nm}$. A volume $(5 \mathrm{ml})$ of the reaction mixture ( $1 \mathrm{~V}$ of $0.2 \% \mathrm{H}_{2} \mathrm{O}_{2} ; 2 \mathrm{~V}$ of $1 \%$ guaïacol; $5 \mathrm{~V}$ of $1 / 15 \mathrm{M}$ phosphate buffer $\mathrm{pH}$ ) was added to $10 \mu \mathrm{l}$ of enzymatic extract. The enzyme activity was evaluated by monitoring optical density change at $420 \mathrm{~nm}$. Peroxidase activity was expressed in UE per $\mu \mathrm{g}$ of proteins contents.

\subsection{Data Analysis}

The data obtained were represented as the mean \pm standard deviation (SD) of at least three independent experiments. All the statistical analyses were conducted using SPSS 20.0 software (SPSS, Inc., Chicago, IL, USA). The one-way analysis of variance (ANOVA) with Student-Newman-Keuls tests was used to compare differences between treatment means when significant $\mathrm{F}$ values were observed at $p$ $<0.05$. 


\section{Results}

\subsection{Two Species of Gnetum (spp.) Plants Obtained from Rooted Cuttings}

Seedlings of Gnetum spp were regenerated from cuttings in pots on a substrate made of topsoil. After four months of planting, seedlings of about $15 \mathrm{~cm}$ were obtained for both species of Gnetum spp. (Figure 1).

\subsection{Influence of Auxins on Roots Cuttings}

Auxins pretreatment promoted rooting rate of cuttings up to a limit threshold in $G$. africanum and $G$. buchholzianum. Hence, in $G$. africanum, peaks of percentage of rooting were obtained with $100 \mathrm{mg} / \mathrm{l} \mathrm{IAA}(77.33 \pm 2.46), 150 \mathrm{mg} / \mathrm{l} \mathrm{IBA}(66.20$ $\pm 3.85)$ and $150 \mathrm{mg} / \mathrm{l} \mathrm{NAA}(61.17 \pm 4.09)$ (Figure 2). In G. buchholzianum peaks of percentage of rooting were observed with $100 \mathrm{mg} / \mathrm{l} \mathrm{IBA}(95.33 \pm 1.71)$, and IAA $(88.33 \pm 2.18)$, and $150 \mathrm{mg} / \mathrm{l} \mathrm{NAA}(88.66 \pm 2.37)$ (Figure 3$)$.

The monitoring of number of roots per cutting showed the best number of roots per cutting with $150 \mathrm{mg} / \mathrm{l} \mathrm{IBA}(8 \pm 1.2)$, IAA $(6.8 \pm 0.5)$ and NAA (5.6 \pm $0.5)$ in $G$. africanum and $150 \mathrm{mg} / \mathrm{l} \mathrm{IBA}(4.9 \pm 0.4)$ and $200 \mathrm{mg} / \mathrm{l} \mathrm{IAA}(4.1 \pm 0.8)$ and NAA (4.6 \pm 0.5$) G$. buchholzianum (Figure 4 and Figure 5). The combination of percentage of cutting rooting and number of roots per cutting indicated that $150 \mathrm{mg} / \mathrm{l} \mathrm{IBA}$ and IAA and $100 \mathrm{mg} / \mathrm{l} \mathrm{NAA}$ are best in rooting for both species. These auxins concentrations were therefore used to monitor phenolic compounds contents, peroxidase and polyphenol oxidase activities at different phase of rooting in $G$. africanum and $G$. buchholzianum.

\subsection{Influence of Exogenous Auxins, Pretreatment on Phenolic Compounds Contents}

Phenolic compounds analysis showed that the content of these secondary metabolites increase from induction to expression phases independently to auxins treatment. However, at a giving phase, phenolic compounds contents were lower in untreated cuttings than that treated with auxin indicating that auxins treatments promote phenolic compounds synthesis in $G$. africanum and $G$. buchholzianum. Additionally, at induction phase, there was no significant difference in phenolic compounds contents between cuttings treated with auxins and

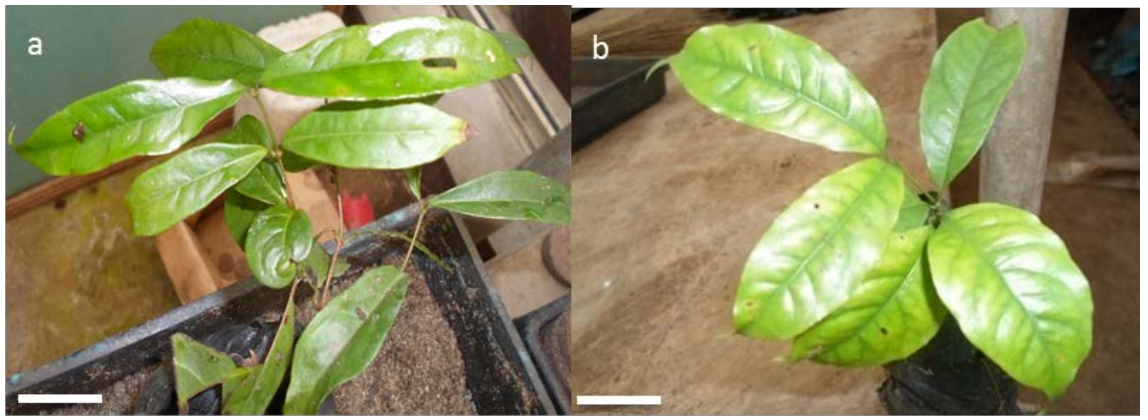

Figure 1. Plants of G. afircanum (a) and G. buchholzianum (b) $($ Bar $=1 \mathrm{~cm})$. 


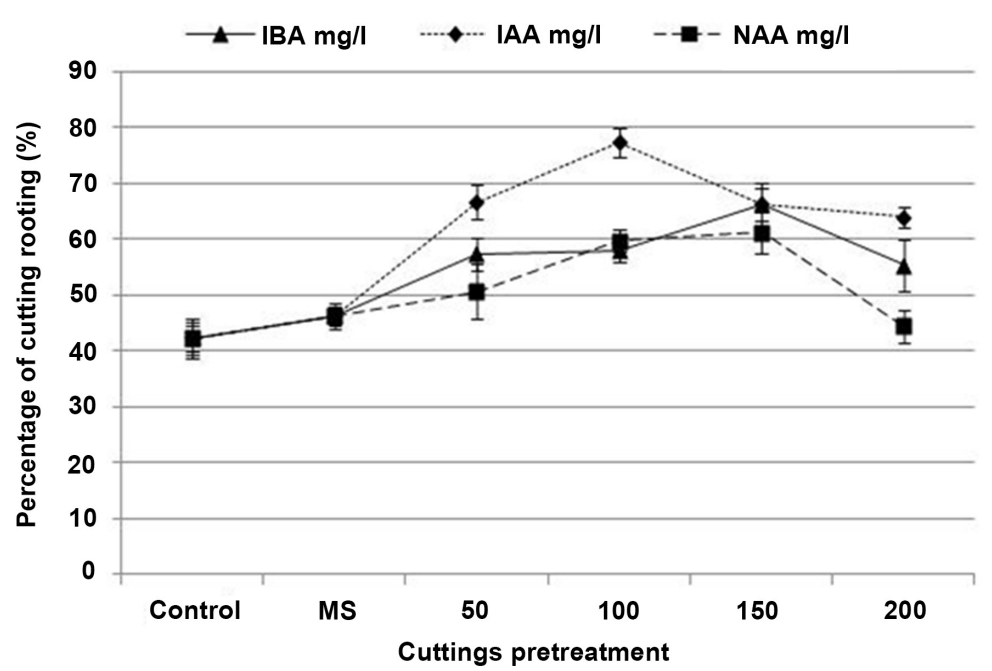

Figure 2. Effect of auxins treatment on percentage of cutting rooting in Gnetum africanum.

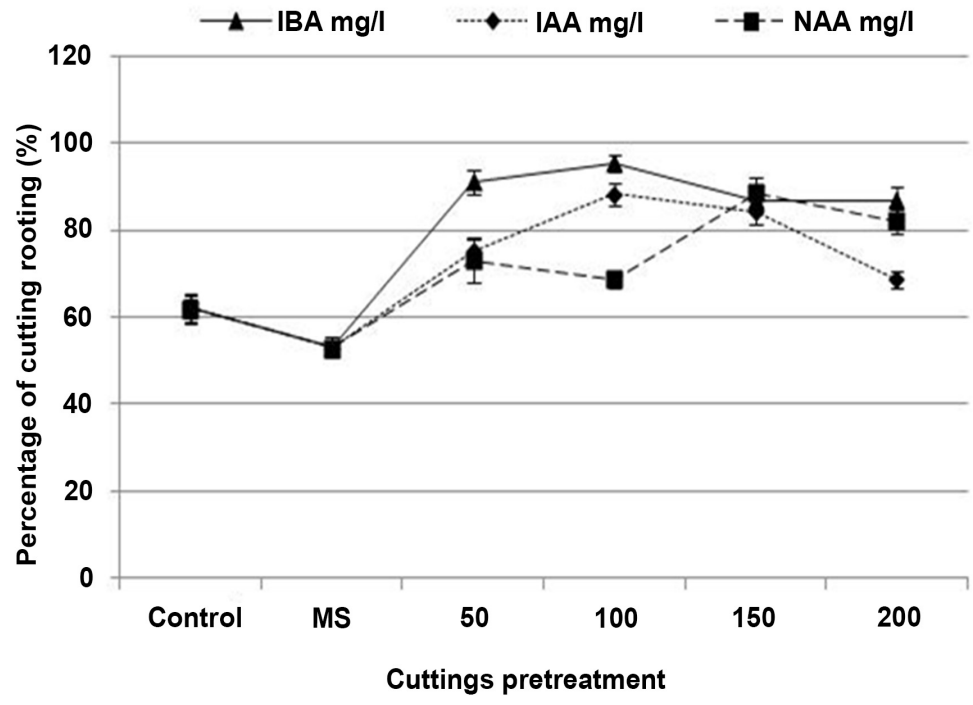

Figure 3. Effect of auxins treatment on percentage of cutting rooting in Gnetum buchholzianum.

untreated cuttings. Significant difference in phenolic compounds contents was observed between cuttings treated with auxins and untreated cuttings at initiation and expression phases in G. buchholzianum (Figure 6). In G. africanum, the difference in phenolic compounds contents between cuttings treated with auxins and untreated cuttings appeared from induction to expression phases (Figure 7).

\subsection{Influence of Exogenous Auxins, Pre-Treatment on Polyphenol oxidase and Peroxidase Activities}

Analysis of polyphenol oxidase contents showed a significant difference in the induction phase due to the function of auxin treatments of both species. During this 


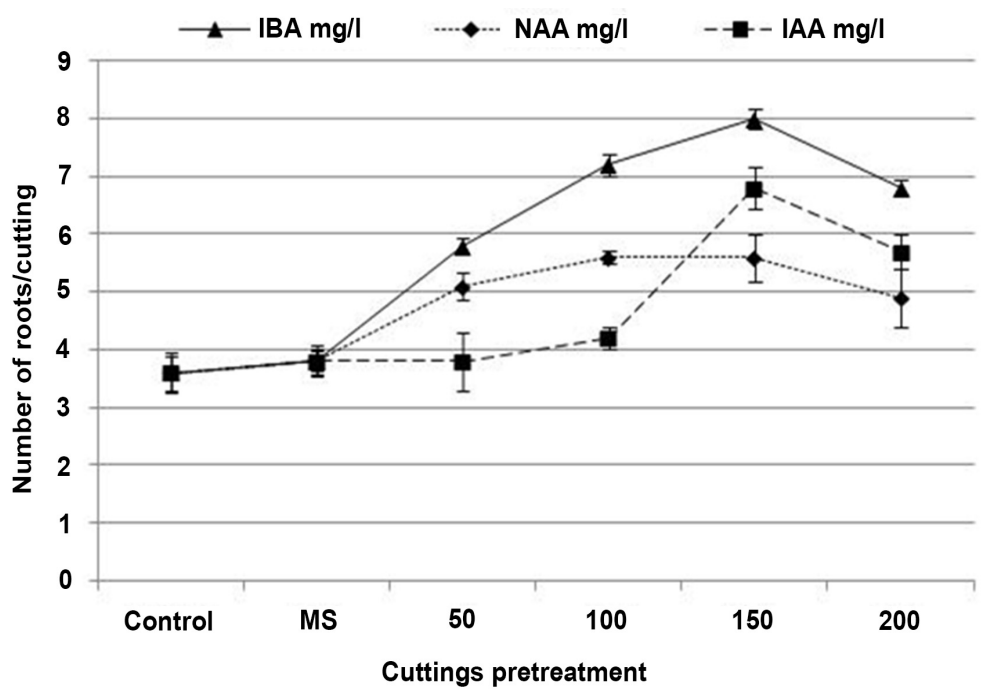

Figure 4. Effect of auxins treatment on number roots/cutting in Gnetum africanum.

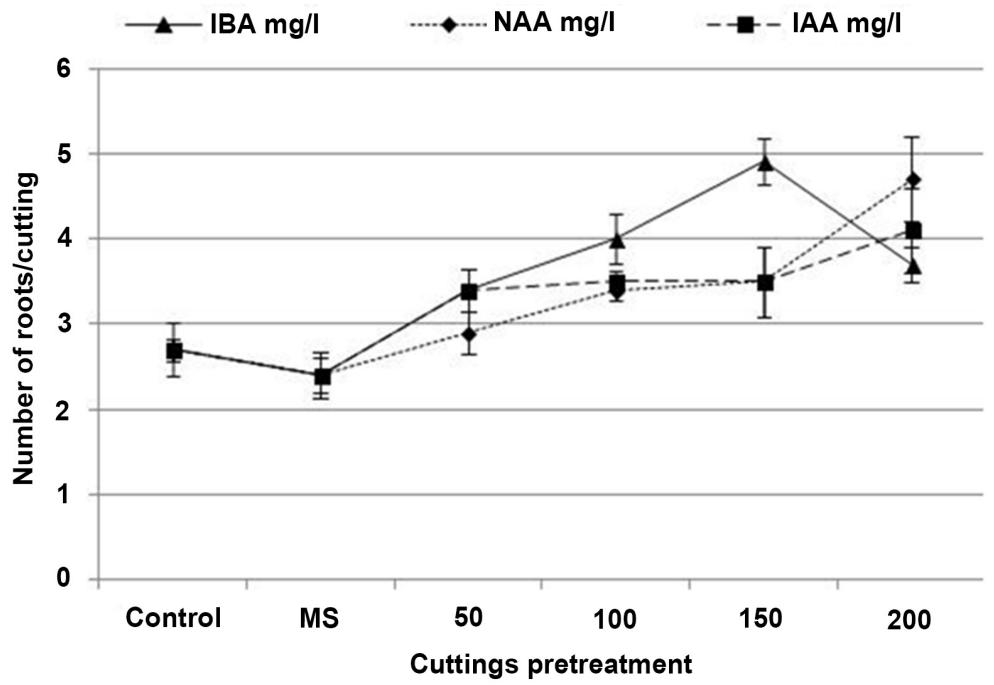

Figure 5. Effect of auxins treatment on number roots/cutting in Gnetum buchholzianum.

phase, polyphenol oxidase contents were high in treated cuttings and weak in untreated cuttings in both species (Figure 8 and Figure 9). During the initiation phase, the polyphenol oxidase contents in treated cuttings were always higher than the polyphenol oxidase contents in untreated cuttings of both species. However, these contents decrease gradually from the induction phase to the initiation phase in treated cuttings, where as in untreated cuttings, these contents remain constant in G. buchholzianum (Figure 8). In contrast, in G. africanum, polyphenol oxidase contents increase progressively in treated cuttings and decline progressively in untreated cuttings from the induction phase to the initiation phase (Figure 9). From the initiation phase to the expression phase, a gradual increase in polyphenol oxidase contents was observed in untreated 


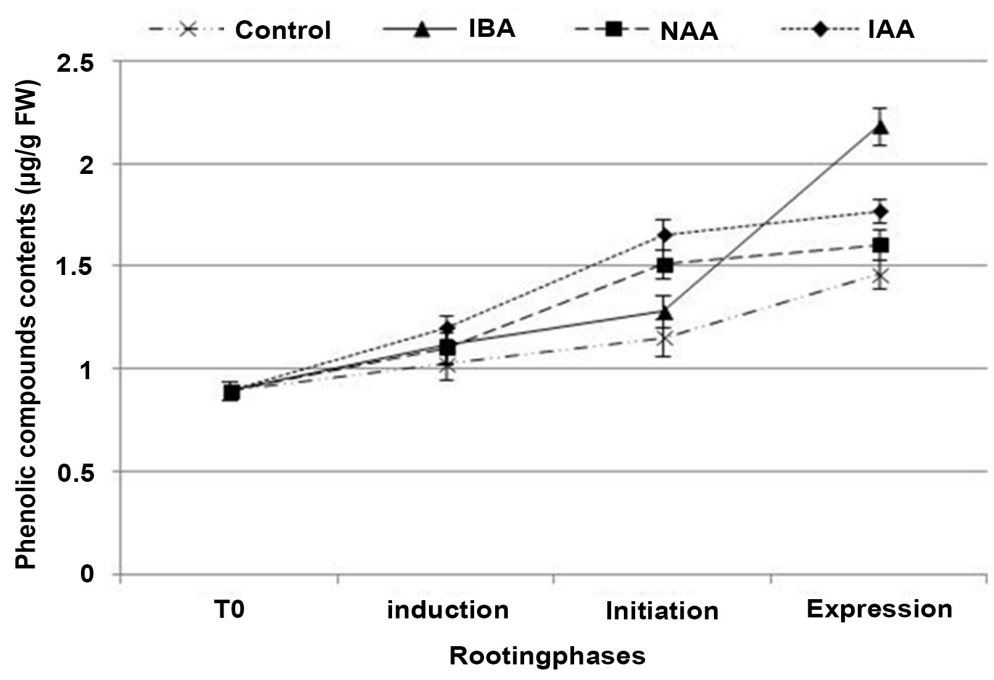

Figure 6. Evolution of phenolic compounds contents during rooting in G. buchholzianum.

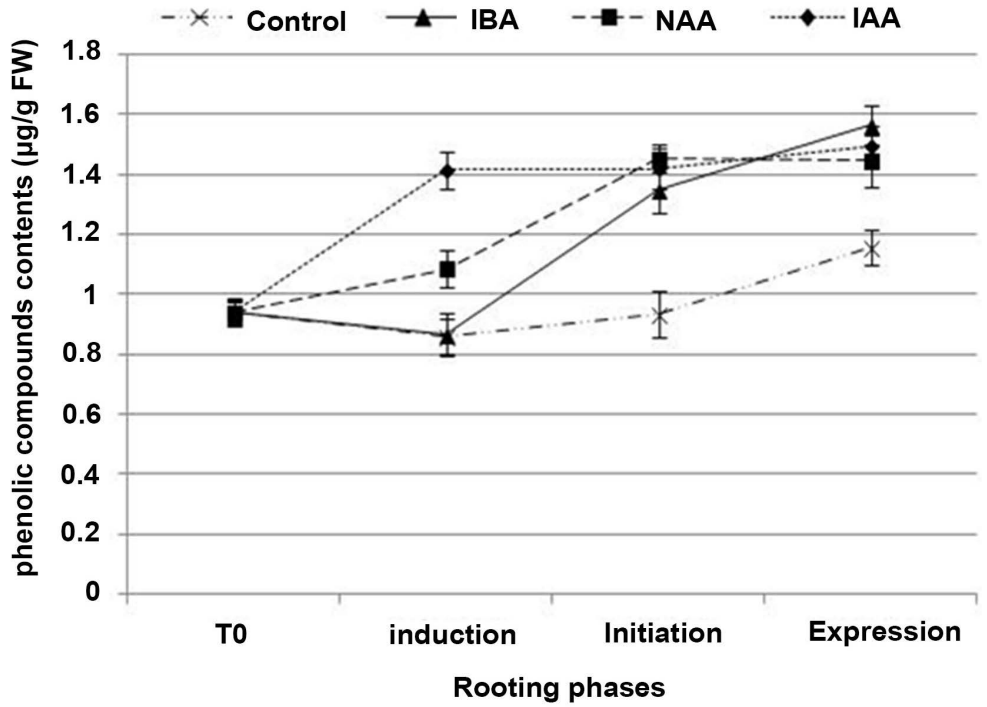

Figure 7. Evolution of phenolic compounds contents during rooting in $G$. africanum.

cuttings as well as in treated cuttings in G. buchholzianum (Figure 8). However, these contents were still higher in treated cuttings than in untreated cuttings. On the other hand, in $G$. africanum, a gradual decline in the contents of polyphenol oxidases from the initiation phase to the expression phase in the treated cuttings was observed while a gradual increase of these contents was observed from the phase of initiation to the phase of expression in untreated cuttings (Figure 9). Otherwise, analysis of peroxidase contents also showed a significant difference in the induction phase as a function of auxin treatments in both species. During this phase, peroxidase contents were also high in treated cuttings and weak in untreated cuttings in both species (Figure 10 and Figure 11). During all the different phases, peroxidase contents in treated cuttings were 


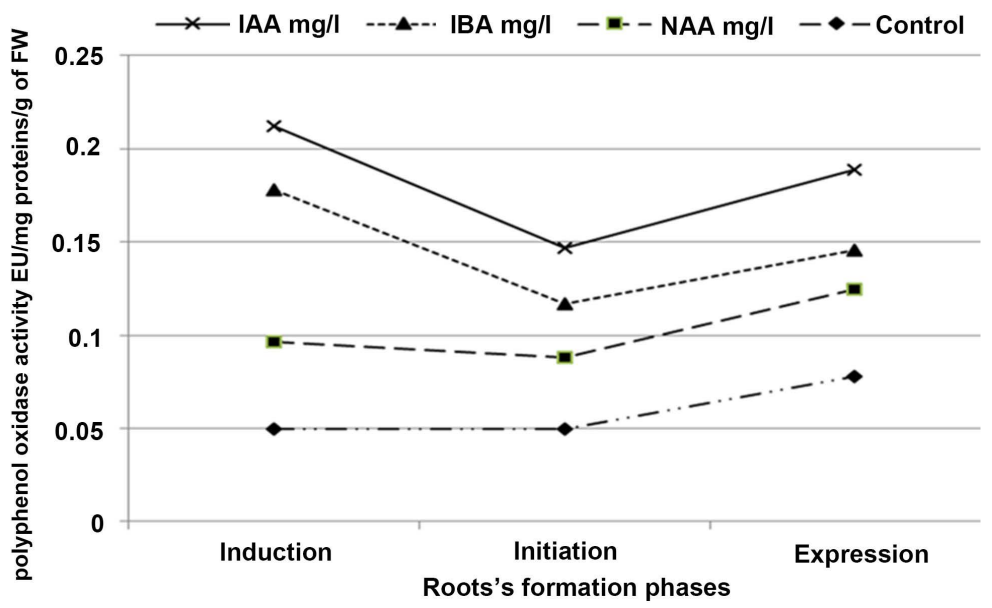

Figure 8. Variation of polyphenol oxidasic activity against roots formation phases in G. buchholzianum.

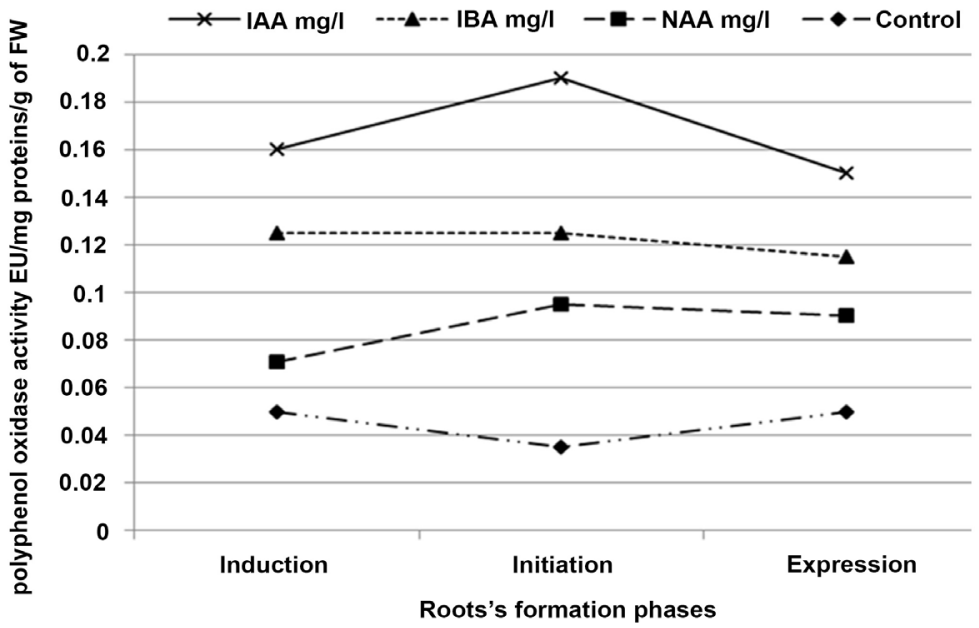

Figure 9. Variation of polyphenol oxidasic activity against roots formation phases in $G$. africanum.

always higher than the peroxidase contents in untreated cuttings in both species (Figure 10 and Figure 11). However, the analysis showed a gradual decline of these contents in induction phase in both treated and untreated cuttings in $G$. buchholzianum (Figure 10). On the other hand, in the G. africanum species, there has been a progressive decrease in the contents of peroxidases from the induction phase to the initiation phase and a gradual increase in these contents of the initiation phase to the expression phase (Figure 11). In view of the results obtained, the soluble proteins are also involved in the formation of adventitious roots.

\subsection{Cellular Modification Bases on Cuttings during the Induction, Initiation and Expression Phases}

The cross-sectional aspects of cuttings bases were observed during the induction, initiation and expression phases under an optical microscope (10 X). The 


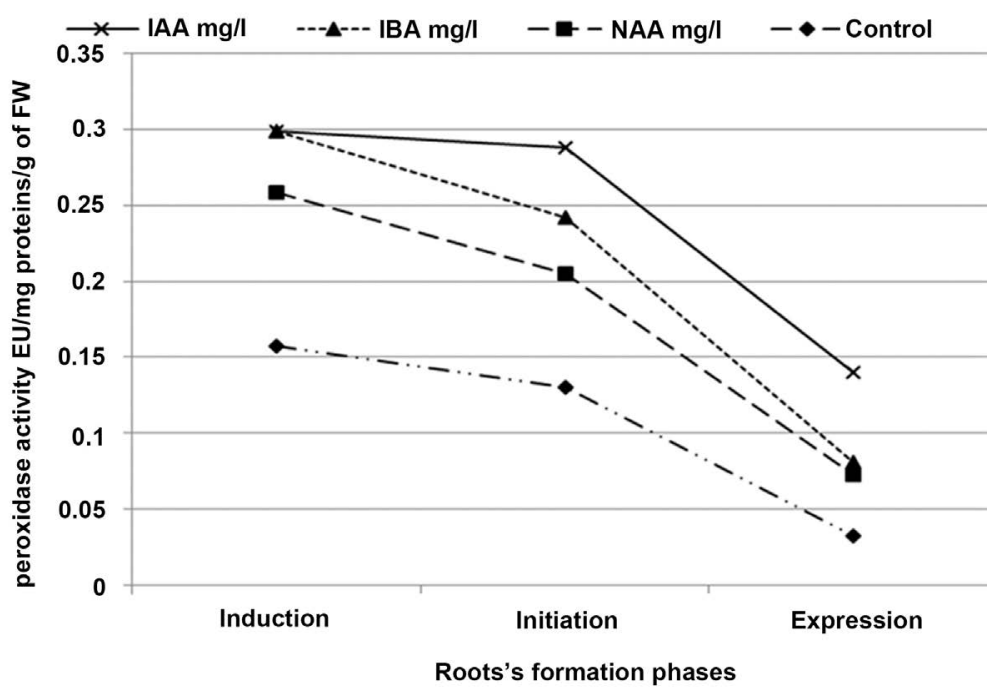

Figure 10. Variation of peroxidasic activity against roots formation phases in G. buchholzianum.

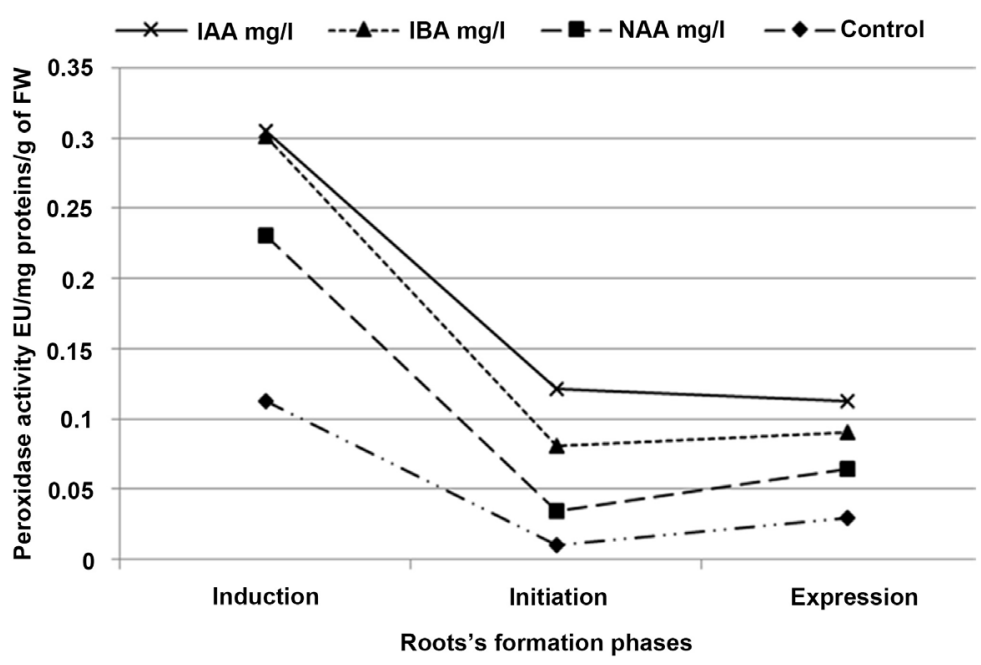

Figure 11. Variation of peroxidasic activity against roots formation phases in $G$. africanum.

results showed a gradual intensification of cell division over time. This intensification was shown to be super imposable to the initiation and expression induction phases during rhizogenesis in Gnetum (spp.) (Figure 12).

\section{Discussion}

The results obtained show that the use of auxins promotes the rooting of cuttings of Gnetum species regardless of the type of auxin used for the pre-treatment. These results are similar to those obtained by [21], who showed that the rooting of cuttings treated with auxins is much better than the rooting of untreated cuttings during the study of the rooting of jojoba cuttings. These results are also similar to those obtained by [22], who showed that semi-woody 


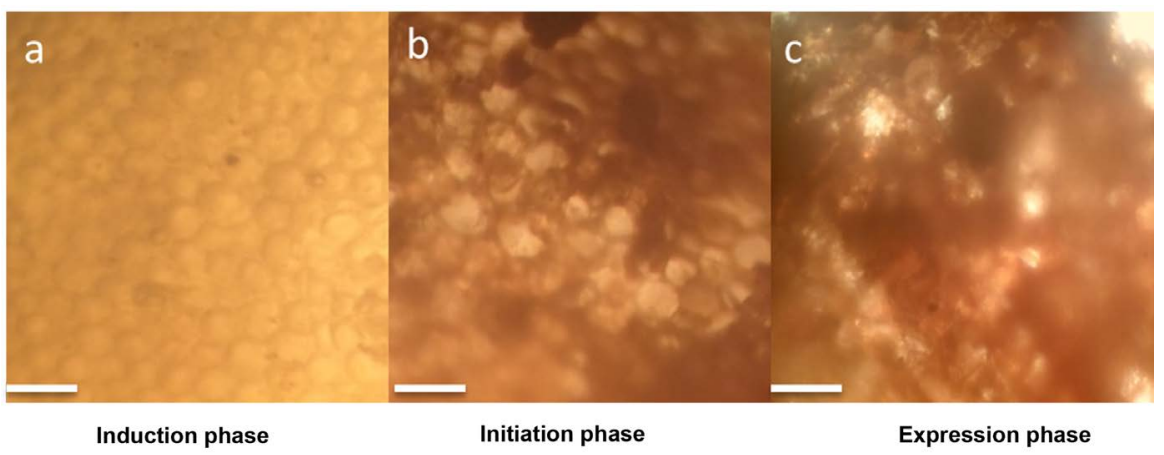

Figure 12. Different Profiles of cellular divisions: induction phase (a), initiation phase (b) and expression phase $(\mathrm{c})$ in an optic microscope $(10 \mathrm{X})(\mathrm{Bar}=1 \mathrm{~cm})$.

cuttings pretreated with indole butyric acid (IBA), had the best rooting rates compared to the rooting rate of untreated cuttings. On the other hand, our results are different from those obtained by [23] Bodjrenou et al., 2018 who showed that NAA and IBA are ineffective in the rhizogenesis of Pterocarpus erinaceus. Identical behavior is reported in Lovoa trichilioides [24] and Dacryodes edulis [25]. These authors showed that different concentrations of IBA. (0; 50; 100; 150 and $200 \mu \mathrm{g}$ ) or different types of hormones (NAA, NAA + IBA, IBA) did not have a significant effect on the rooting of stem cuttings of Meliaceae and Burseraceae respectively. The results show that among the auxins used (IBA, IAA and NAA), IBA treatment provides better rooting rates, followed by IAA, then NAA respectively on cuttings. These results are similar to those obtained by [26] and [21] in the study of rhizogenesis of semi-woody cuttings of Simmondsia chinensis. These results do not take into consideration the types of substrates used because [27] showed that the typical substrate factor significantly influences the rate of rooting in the study of Cola acuminata cuttings.

Analysis of results also shows an increase in the content of phenolic compounds in treatments where rooting is important. This content intensifies at the initiation phase in $G$. africanum and the expression phase in $G$. buchholzianum for almost all treatments. These results are similar to those obtained by [28] who showed that phenolic compounds would be involved in rooting during the study of adventitious root formation. These results suggest that phenolic compounds would protect auxins against enzymes that destroy their structure or modify them, making them more available in the cell. This would result in the free diffusion of auxin molecules across the cell membrane without interaction with other molecules. For this purpose, the phenolic compounds prevent the IAA conjugation, increase its free quantity and increase the rooting of the plants by regulating by inhibition, the exaggerated decarboxylation of the IAA especially in case of injury of the plants. The main phenolic compounds involved are ortho- and para-diphenols, as well as methyl tri-phenols [28]. NAA is not decarboxylated and is activated by conjugation in contrast to IAA which is decarboxylated and conjugated. Therefore a high concentration of IAA is lowered by 
the phenolic compounds. The strong decarboxylation is observed from the first days of the cuttings in the culture medium. Tri-phenols, O-diphenols and Mdiphenols reduce the decarboxylation of IAA, thus promoting cell division and hence root set up. Monophenols have been suggested as IAA oxidase cofactors and because of this, increase the decarboxylation of IAA. Coumarin acid has no similar effect but mono-phenolic salicylic acid increases the decarboxylation of IAA [28]. Some studies have shown that certain phenolic compounds (chlorogenic acid, caffeic acid, catechol gallic acid and ferulic acid) play a role of rooting cofactors, especially as protectors of IAA against oxidation. They are recognized as competitive substrates for IAA-oxidase [29].

Moreover, the results show a high content of peroxidases and polyphenol oxidases during the different phases of rhizogenesis for the treatment with the best results of rhizogenesis. These results could be explained by the fact that the genes of the proteins involved in root differentiation would be activated during these phases. This quantity of protein synthesis is thus proportional to the control of multiple divisions and cellular interactions involved. Some authors [30] reported through their work on mussel cuttings that the total protein content increased very slightly during the first phase of root development. Similar results were obtained with polyphenol oxidases in Gnetum africanum. On the other hand, the different results were obtained with these polyphenol oxidases in the species Gnetum buchholzianum and with the peroxidases in the two species. The content of polyphenol oxidases was found to be high at the initiation stage in the Gnetum africanum species at initiation phase. These results show that the protein content will vary according to the type of proteins and the genotype of the species during the different stages of rooting. However, these auxins intervent in the synthesis of proteins already present in the plant. Other authors [31] showed that enzyme content begins to increase in IBA treatment in Pinus radiata during the first day but intensifies at 7 days. These results are similar to the results obtained during rhizogenesis in Gnetum (spp.). This trend would be proportional to the amount of RNA, suggesting that high enzyme synthesis is preceded by the synthesis of mismatched RNAs. Many authors [30] noted an increase in soluble enzyme content in the first phase of root formation. These results suggest that enzymes that are likely to participate in rooting are mostly synthesized during this period. Nevertheless, there is a low enzyme synthesis at the expression phase for the treatments whose results are better, would mean that these enzymes are at the end of their activity, leading directly to the appearance of the roots.

Overall, enzymatic activities showed significant variation in cuttings treated with auxin compared to control in both species of Gnetum. Thus, exogenous auxin supplementation enhances polyphenol oxidase and peroxidase activities in individuals under stress caused by the injury. The considerable decrease in peroxidase in both species may be related to the detoxification of the cell by this enzyme at the induction and initiation phases. This detoxification is focused on the oxidation of certain substrates such as auxin. The purpose of this detoxifica- 
tion is to eliminate reactive oxygen species caused by wounds on cuttings fragments such as [32] describes it in the case of stress caused by exogenous phenolic compounds. However, at the root emergence phase, auxin becomes inhibitory to the synthesis of this enzyme. There is a close correlation between this variation and the establishment of roots and this in relation to the type of plant. Moreover, [33] reported the same observations on Olea europaea, concluding that the decrease in peroxidase activity at the initiation phase was associated with the ability of some plant species to generate roots. A slight increase in the activity of this enzyme in the expression phase for control and auxin treatment in $G$. africanum is thought to be related to the genetic factors of the species. Regarding polyphenol oxidases, the results showed a decrease in activity at the expression phase in Gnetum africanum and an increase in activity at the expression phase in Gnetum buchholzianum for all treatments. These results could be explained by the fact that there would be a negative feedback control, inhibiting the synthesis of this enzyme in the species in order to preserve a considerable stock of phenolic compounds necessary for the cellular reconstitution in Gnetum africanum. Increasing the content of peroxidases or polyphenol oxidases during the expression phase in a particular species would result in the need for a large amount of these enzymes for the oxidative phenomena necessary for rooting. In addition, [33] have shown the action of polyphenol oxidases in the formation of the IAA-phenol complex from IAA. This molecule is a cofactor for the formation of adventitious roots and their development. The activity of peroxidases and polyphenol oxidases evolving almost in the same direction is contrary to the results obtained by [33] who showed that the peroxidases and polyphenol oxidases varied inversely, which coincides with the mitotic dynamism that governs the formation of meristems. There are intrinsic factors such as the genetic factors that would influence these different activities for root formation.

\section{Conclusion}

The results obtained showed that the auxins treatments and particularly the IBA improve the rooting rate of cuttings in Gnetum africanum and Gnetum buchholzianum. At the end of the results obtained, treatment with IBA at $150 \mathrm{mg} / \mathrm{l}$ gives the best rooting rate in both species of Gnetum. Moreover, biochemical markers, in this case, the phenolic compounds as well as soluble peroxidases and polyphenol oxidases have shown their involvement in rooting in these two species of Gnetum. Phenolic compounds as well as peroxidases and polyphenol oxidases would, therefore, be good biochemical markers directly involved in the control of root formation in Gnetum (spp.).

\section{Acknowledgements}

The authors would like to thank the Director of the Institute of Agricultural Research for Development (IRAD) of Ekona for allowing this research work to be done in the Plant Biotechnology laboratory. 


\section{Conflicts of Interest}

The authors declare no conflicts of interest regarding the publication of this paper.

\section{References}

[1] Lowe, J. (1984) Gnetum in West Africa. Nigerian Field, 49, 99-104.

[2] Chaw, S., Parkinson, C.L., Cheng, Y., Vincent, T.M. and Palmer, J.D. (2000) Seed Plant Phylogeny Inferred from All Three Plant Genomes: Monophyly of Extant Gymnosperms and Origin of Gnetales from Conifers. Proceedings of the National Academy of Sciences, 97, 4086-4091. https://doi.org/10.1073/pnas.97.8.4086 https://www.pnas.org/content/97/8/4086.full

[3] Ali, F., Assanta, M.A. and Robert, C. (2011) Gnetum africanum: A Wild Food Plant from the African Forest with Many Nutritional and Medicinal Purposes. Journal of Medicinal Food, 14, 1289-1297. https://doi.org/10.1089/jmf.2010.0327

[4] Ballester, A., Vidal, N. and Vieitez, A.M. (2009) Developmental Stages during in Vitro Rooting of Hardwoods Trees with Juvenile and Mature Characteristics. In: Niemi, K. and Scagel, C., Eds., Adventitious Root Formation of Forest Trees and Horticultural Plants-From Genes to Applications, Research Signpost, Thiruvananthapuram, 277-299.

[5] Hartmann, H.T., Kester, D.E. and Davies, F.T. (1990) Plant Propagation: Principles and Practices. Prentice Hall, Englwood Ciffs, 246-247.

[6] De Klerk, G.J., Krieken, W.V.D. and Jong, J. (1999) The Formation of Adventitious Roots: New Concepts, New Possibilities. In Vitro Cellular and Developmental Biology, 35, 189-199. https://doi.org/10.1007/s11627-999-0076-Z

[7] Gaspar, T., Kevers, C. and Hausman, J.F. (1997) Indissociable Chief Factors in the Inductive Phase of Adventitious Rooting. Biology of Root Formation and Development, 65, 55-63. https://doi.org/10.1007/978-1-4615-5403-5_9

[8] Haissig, B.E. and Davis, T.D. (1994) An Historical Evaluation of Adventitious Rooting Research to 1993. In: Davis, T.D. and Haissig, B.E., Eds., Biology of Adventitious Root Formation, Springer, Berlin, 275-331. https://doi.org/10.1007/978-1-4757-9492-2_19

[9] Heloir, M.C., Kevers, C., Hausman, J.F. and Gaspar, T. (1996) Changes in the Concentrations of Auxins and Polyamines during Rooting of In-Vitro-Propagated Walnut Shoots. Tree Physiology, 16, 515-519. https://doi.org/10.1093/treephys/16.5.515

[10] Luckman, G.A. and Menary, R.S. (2002) Increased Root Initiation in Cuttings of Eucalyptus nitens by Delayed Auxin Application. Plant Growth Regulation, 38, 31-35. https://doi.org/10.1023/A:1020926114165

[11] Sachs, T. (2005) Auxins Role as an Example of the Mechanisms of Shoot/Root Relations. Plant Soil, 268, 13-19. https://doi.org/10.1007/s11104-004-0173-Z

[12] Cheniany, M., ebrahimzadeh, H., Masoudi-Nejad, A., Vahdati, K. and LesliE, C. (2010) Effect of Endogenous Phenols and Some Antioxidant Enzyme Activities on Rooting of Persian Walnut (Juglans regia L.). African Journal of Plant Science, 4, 479-487. http://www.academicjournals.org/ajps

[13] Fu, Z., Xu, P., He, S., Teixeira Da Silva, J.A. and Tanaka, M. (2011) Dynamic Changes in Enzyme Activities and Phenolic Content during in Vitro Rooting of Tree Peony (Paeonia suffruticosa Andr.) Plantlets. Maejo International Journal of 
Science and Technology, 5, 252-265.

[14] Murashige, T. and Skoog, F. (1962) A Revised Medium for Rapid Growth and Bioassays with Tobacco Tissue Cultures. Physiologia Plantarum, 15, 473-497. https://doi.org/10.1111/j.1399-3054.1962.tb08052.x

[15] Macheix, J.J. (1974) Les esters hydroxynnamiques de la pomme de terre: Identification, variations au cours de la croissance du fruit et métabolisme. Thèse Doct. Etat, Paris, 168.

[16] Bray, H.G. and Thorpe, W.V. (1954) Analysis of Phenolic Compounds of Interest of Metabolism. Methods of Biochemical Analysis, 1, 27-52. https://doi.org/10.1002/9780470110171.ch2

[17] Bradford, M.M. (1976) A Rapid and Sensitive Method for the Quantitative of Microgram Quantities of Protein Utilizing the Principe of Protein-Dye Binding. Analytical Biochemistry, 2, 248-254. https://doi.org/10.1016/0003-2697(76)90527-3

[18] Macedo, E., Vieira, C., Carrizo, D., Porfírio, S., Hegewald, H., Arnholdt-Schmitt, B., Calado, M.L. and Peixe, A. (2013) Adventitious Root Formation in Olive (Olea europaea L.) Microshoots: Anatomical Evaluation and Associated Biochemical Changes in Peroxidase and Polyphenoloxidase Activities. The Journal of Horticultural Science and Biotechnology, 88, 53-59. https://doi.org/10.1080/14620316.2013.11512935

[19] Van Kammen, A. and Broumer, D. (1964) Increase of Polyphenoloxidase Activity by a Local Virus Infection in Uninoculated Parts of Leaves. Virology, 22, 9-14. https://doi.org/10.1016/0042-6822(64)90042-X

[20] Thorpe, A.P., Tran Thanh Van, K.M. and Gaspar, T. (1978) Isoperoxidases in Epidermal Layers of Tobacco and Changes Organ Formation in Vitro. Physiologia Plantarum, 44, 388-394. https://doi.org/10.1111/j.1399-3054.1978.tb01643.x

[21] Houar, F.Z., Daroui, E.A., Boulghalagh, J., Boukroute, A., Kouddane, N. and Berrichi, A. (2014) Effet des différents types d'auxines sur l'enracinement des boutures du jojoba (Simmondsia chinensis L.). Nature and Technology, 11, 46-51.

[22] Laribi, B., Touil, R., Kouki, K. and Bettaieb, T. (2013) Multiplication par bouturage d'un écotype Tunisien d'Eglantier (Rosa canina L.). Nature and Technologie, 9, 55-59.

[23] Bodjrenou, T.R., Houètchégnon, T., Keita, N.T. and Ouinsavi, C. (2018) Effets de l'acide naphtalène acétique, du type de substrat et de la grosseur des boutures sur le bouturage de tige de Pterocarpus erinaceus Poir. (Fabaceae). European Scientific Journal, 14, 297-316. https://doi.org/10.19044/esj.2018.v14n27p297

[24] Tchoundjeu, Z. and Leakey, R.R.B. (2001) Vegetative Propagation of Lovoa trichilioides. Effects of Provenance, Substrate, Auxins and Leaf Area. Journal of Tropical Forest Science, 13, 116-129.

[25] Mialoundama, F., Avana, M.L., Youmbi, E., Mampouya, P.C., Tchoundjeu, Z., Mbeuyo, M., Galamo, G.R., Bell, J.M., Kopguep, F. and Tsobeng, A.C. (2002) Vegetative Propagation of Dacryodes edulis (G. Don) HJ Lam by Marcots, Cuttings and Micropropagation. Forests, Trees and Livelihoods, 12, 85-96.

https://doi.org/10.1080/14728028.2002.9752412

[26] Choffe, K.L., Murch, S.J. and Saxena, P.K. (2000) Regeneration of Echinacea purpurea: Induction of Root Organogenesis from Hypocotyl and Cotyledon Explants. Plant Cell, Tissue and Organ Culture, 62, 227-234. https://doi.org/10.1023/A:1006444821769

[27] Paluku, P.A., Okungo, A. and Bwama, M. (2018) Bouturage de Cola acuminata (P. 
Beauv.) Schott \& Endl.: Influence du substrat, de la longueur et de la surface foliaire sur l'enracinement de boutures à Kisangani, RD Congo. Journal of Applied Biosciences, 123, 12354-12362. https://doi.org/10.4314/jab.v123i1.4

[28] De Klerk, G.J., Guan, H., Huisman, P. and Marinova, S. (2011) Effects of Phenolic Compounds on Adventitious Root Formation and Oxidative Decarboxylation of Applied Indole Acetic Acidin Malus'Jork 9. Plant Growth Regulation, 63, 175-185. https://doi.org/10.1007/s10725-010-9555-9

[29] Krajnc, A.U., Turinek, M. and Ivančič, A. (2013) Morphological and Physiological Changes during Adventitious Root Formation as Aected by Auxin Metabolism: Stimulatory Eect of Auxin Containing Seaweed Extract Treatment. Agricultura, 10, 17-27.

[30] Nag, S., Paul, A. and Choudhuri, M. (2013) Role of Endogenous Nucleic Acids and Proteins in Adventitious Root Formation in Mung Bean Cuttings. International Journal of Innovative Research in Science, Engineering and Technology, 2, 1337-1341.

[31] Li, M. and Leung, D.W.M. (2001) Protein Changes Associated with Adventitious Root Formation in Hypocotyls of Pinus radiata. Biologia Plantarum, 44, 33-39. https://doi.org/10.1023/A:1017910018880

[32] Vojin, T., Snezana, M., Aleksandar, C., Marija, P., Milana, T., Dragana, A., Tadić, J. and Subotić, A. (2014) Production of Hairy Root Cultures of Lettuce (Lactuca sativa). Central European Journal of Biology, 9, 1196-1205. https://doi.org/10.2478/s11535-014-0351-9

[33] Aslmoshtaghi, E. and Shahsavar, R. (2016) Peroxidase, Polyphenoloxydase and Protein Changes in Olives during Adventitious Root Formation. Trakia Journal of Sciences, 14, 176-182. https://doi.org/10.15547/tjs.2016.02.010 